\title{
TAMÁS SÁRKÖZY*
}

\section{Post-Socialist "Primitive Accumulation of Capital" and the Law}

\begin{abstract}
The study deals with theoretical questions of the Hungarian privatization law. It clarifies the differences between the economic and legal concept of privatization, the various interpretations of privatization. The Hungarian privatization was the earliest and at the same time-after the German-the quickest completed privatization in the former socialist countries. It reviews the so-called spontaneous privatization between 1988-1990, and the privatization legislature of 1992 and 1995 as well. As a conclusion the study deals with the evaluation of the privatization law, and with the consequences of privatization with regards to social politics.
\end{abstract}

Keywords: post-socialist privatization, management, business law, investment, foreign capital, AP, rule of law, market economy, competition, state property, national property, administrative modernization, accumulation of capital, EU business law

1. A specific area of the law of political transformation in Central-EasternEurope is constituted by the law of privatisation, which qualifies as an antithesis to the law of the economic evolution of socialism, scilicet, the law of nationalisation. It is a mere provisional area of law, since it is dispensable in mature capitalism, therefore, it will gradually erode from Hungarian business law.

In economic sociological literature and subsequently, in mass communication, the term of privatisation is applied in a much broader sense than its Hungarian term is circumscribed under positive law. For instance, in American social science literature, privatisation defines the decrease of the intervention of the state into economic and social processes, thereby, as a collective term, it encompasses liberalisation, decentralisation and deregulation. ${ }^{1}$ Whereas, in Hungary the establishment of private enterprises that had accrued from their

* Professor of Law, Corvinus University of Budapest, H-1093 Budapest, Fővám tér 8. E-mail: amarill.fogarasi@uni-corvinus.hu

1 See, e.g., Savas, E. S.: Privatisation. The Key to Better Government. New Jersey, 1987.; T. Clarke, T.-Pitales, C. (eds.): The Political Economy of Privatisation. LondonNew York, 1994.; Mihályi, P.: A magyar privatizáció krónikája 1989-1997 (A Chronicle of Hungarian Privatisation between 1989-1997). Budapest, 1998. 
own resources, the so-called crop investments of foreign capital and the evolution of the proprietary status of the members of co-operatives within cooperatives have been several times defined as privatisation. As a matter of course, these elements have contributed to the evolution of the "private" character of Hungarian society, but de jure, these do not qualify as privatisation. It is not privatisation in a narrower legal sense, either, when the state transfers assets generally for free to other forms of public property, e.g., to the property of regional and local governments, public bodies (e.g., the Hungarian Academy of Sciences) or to the church (albeit, the latter transaction is also termed as reprivatisation, since a significant share of the property of the church had been nationalised during socialism).

In terms of Hungarian positive law, privatisation implies the transfer of state-owned property to private property. Therefore, privatisation shall not encompass the transfer of assets that are not owned by the state, but by other public proprietor (e.g., local government) into private property. Finally, it does not constitute privatisation either, when the private proprietor does not acquire property, but e.g., rights of usufruct (so-called privatisation of rights of commons and functions, e.g., via concessions in case of state monopolies or via the so-called privatisational leasing). The term of private proprietor with respect to privatisation was positively defined under Para. (4) of Article 1 of Act 39 of 1995 on the Sale of State-Owned Venture Capital (hereinafter: AP).

Nevertheless, we need to further narrow the legal concept of privatisation. Hungarian law pertaining to privatisation (from the outset, but as it is most completely incorporated under Act 39 of 1995, i.e., under AP) renders the concept of privatisation by circumscribing it as the sale of shares exclusively in state-owned associations (stocks, business shares in limited liability companies) to private proprietors via privatisation agreements. Other forms of the cessation of state-owned property, e.g., the alienation of real estates or art treasures under deeds of sale and selling off via liquidation procedures, etc. (so-called hidden or intangible privatisation $)^{2}$ did not fall under the effect of AP. Scilicet, AP endeavoured to regulate exclusively the sale of business shares in stateowned companies, that is, enterprises functioning in the form of joint-stock or limited liability companies. These were defined as the so-called venture capital of the state, which could or needed to be sold by the state pursuant to AP. Namely, this property could persist only provisionally as state property, since it needed to be privatised with the exception of the narrow scope of public utility companies, which were designed to persist as long-term state property

${ }^{2}$ See, e.g., Szanyi, M.: Csőd, felszámolás, végelszámolás mint a privatizáció útja (Bankruptcy, Liquidation and Full Settlement As Ways of Privatisation). Budapest, 1998. 
and to be transferred to the scope of government property after the completion of the process of privatisation. ${ }^{3}$ Further narrowing of the scope of privatisation consisted in the stipulation under AP that the transfer of assets free of charge shall not qualify as privatisation, either, but that could be effected only exceptionally pursuant to a statute. Privatisation shall be effected on grounds of a mixed and non-typical sales agreement concluded in compliance with the Sale of Goods Act, therefore, the conceptual element of privatisation agreements is countervalue. Privatisation shall be generally implemented at real value in return for cash (therefore, Hungarian privatisation qualified as market privatisation as opposed to privatisation by coupons implemented in the great majority of former socialist states). However, concessional privatisation techniques, furthermore, services in kind instead of cash as equivalent (e.g., discharge via environmental protection) were alike admissible. ${ }^{4}$

2. It is a frequent phrase that the underlying dynamics of privatisation in Hungary consisted in the intention of the increase of the income of the central budget and in the claim of company management to retain their positions and acquire property. This assumption, according to my opinion, reflects merely the surface. Namely, as opposed to that in Western-European countries, privatisation in Hungary and generally in the former socialist states equalled $a$ privatisation entailed by political transformation in two senses of the term, since it both transformed the proprietary structure and it constituted the sine qua non of the functioning of civil states founded on the rule of law and of bourgeois market economies.

3 The distinction of the venture, i.e., business capital of the state from government property to be sold according to more rigorous sales rules did not ensue before 2008. See: Bencze, I.: A kincstári vagyon a jog tükrében. Számadás a talentumról (Government Property As Reflected by Law. An Account on Talents). Budapest, 1998. 28-30.

4 We can refer to e.g., property notes, then the issuance of employees' shares, the purchase of concessional shares by small investors, furthermore, the Existential-Credit Programme and the Employees Share Scheme (MRP). On the conceptual basis of concessional shares, see, Diczházi, B.: A népi részvényszocializmus vázlata (A Sketch of People's ShareSocialism). Figyelö, 1988. 45, and Lukács, J.: A gazdaság demokratizálásának útja. A munkavállalók részvénytulajdonlásáról a magyar gazdaságban (The Process of the Democratisation of Economy. On the Ownership of Shares by Employees in Hungarian Economy). Budapest, 1990. See further, Gidai, A.: Kedvezményes privatizációs technikák (Concessional Privatisation Techniques). Budapest, 1998. 
Thence, without the privatisation of the major part of state property

a) the Hungarian state founded on the rule of law could not have evolved, since that would have been hindered by the persisting dual-nature of the state, the unity of the proprietary and executive powers inherited from socialism. Scilicet, what public authorities by reason of the democracy based on the multi-party system and the doctrine of the division of powers cannot implement, could have been enforced by the state as a proprietor via its power of discretion deriving from its right of ownership. It was the dissolution of the unity of the powers of the state as an executive authority and a proprietor that was essential and in this sense, it was equally indifferent what the scale of the revenues of the state deriving from privatisation was, or, what kind of background and professions the private persons acceding to power had had.

b) Hungarian market economy based on competition could not have evolved, since the monolithic unity of state property, the overwhelming superior economic power of the state would have precluded the evolution and consolidation of real market processes, blocked free market competition, thereby, the state would have gained the upperhand of the private enterprises of its citizens in the market.

Western-European privatisation in those states, where significant nationalisation had indeed ensued, that is, in Austria, Italy, France and England, was system-immanent privatisation, since state property anacronistic in the system of private property was reprivatised. These Western states could afford gradual privatisation under auspicious economic conditions, furthermore, a relatively meagre scale of property was concerned, for instance, 17 p.c. of the national property in case of Austria, which disposed of the highest extent of state property. Besides, privatisation per se could take place with application of the methods of the Stock Exchange, since state ownership concerned not the company, but the stock, therefore, neither company reorganisation, nor asset assessment or the elaboration of special privatisation law was necessary. Whereas, in Hungary, the overwhelming majority of national property needed to be privatised the sooner the better with the initial absence of the methods of the Stock Exchange. ${ }^{5}$ En passant, by reason of our compliance with the Soviet model of

5 See, Korányi, T. G.: Privatizáció a tözsdén keresztül (Privatisation via the Stock Exchange). Budapest, 2000. 
nationalisation, state-owned companies ${ }^{6}$ had had to be artificially reorganised into business associations and only subsequently could they be privatised. With some exceptions, in former socialist states de jure privatisation, that is, the adoption of the associational structure, and social-economic privatisation, that is, the transfer of the shares of associations into private property were separated, furthermore, privatisation could not be effected via the available general instruments of the legal system, but a distinct and provisional area of law had to be elaborated and a distinct system of institutions was also incorporated into the state establishment for the purpose of the enforcement of privatisation entailed by the political transformation. Necessarily, privatisation took place in two stages and in the absence of a consolidated system of market relations, therefore, the available methods of property assessment were anomalous. According to my view, however, privatisation in Central-EasternEurope was autotelic from a taxonomic point of view: for the purposes of the evolution of the civil state founded on the rule of law and of bourgeois market economy, privatisation was an "imperative", even if it was deemed detrimental from the point of view of short- or long-term economic policy. ${ }^{7}$

We need to specify some relevant counter-arguments against privatisation. Privatisation should not be effected in a situation of economic crisis (the dissolution of the Council for Mutual Economic Assistance, the loss of the Soviet market, a situation in which the bankruptcy of the central budget is anticipated, etc.). That is valid. Privatisation in Hungary did not dispose of a social-economic strategy, and as a matter of fact, we did not know what the object of and the value of the object of privatisation exactly was. That is valid. However, nor did other former socialist countries dispose of such a strategy, including the former GDR. Privatisation was launched without adequate

${ }^{6}$ Two exceptions: The companies of the former GDR were transformed into jointstock companies and limited liability companies under the so-called Mantellgesetz of 1990, which prescribed them uniform capital stock and nominal capital. (See, Krüger, H. H.Kühnel, M.-Thomas, S. (eds.): Transformationsprobleme in Ostdeutschland (Problems of the Transformation in East Germany). Opladen, 1990. Whereas, in the successor states of the former Yugoslavia, by reason of the system of corporate governance by employees, a three-graded reorganisational process was applied: social governance-state property-legal privatisation-economic privatisation. See, e.g., Büschenfeld, H.: Privatisierung, 'gesellschaftlichen Eigentums' in der Nachfolgerstaaten Jugoslawien (Privatisation and National Property in the Successor States of Former Yugoslavia). Osteuropa, 35 (1995) No. 3.

7 E.g., it is presumably reasonable that Béla Csikós Nagy describes several aspects of the privatisation entailed by the political transformation as detrimental from the point of view of economic policy. A XX. század magyar gazdaságpolitikája (Economic Policy in Hungary in the $20^{\text {th }}$ Century). Budapest, 1996. 241-280. 
economic, technical and personnel prerequisites, wherefore, an array of cases of abuse could occur in its process. That is also valid, but that was the smaller evil, since this way the economic change of regime sooner ensued in Hungary than in any other former socialist state with the exception of the former GDR, furthermore, we could also escape the road of state-capitalism, which emerged in the majority of the successor states of the former Soviet Union. En passant, privatisation in Hungary was by far more regulated than in the neighbouring states, and according to estimates, the scale of abuses was also much lower: we did not make it from planned economy back to clans. ${ }^{8}$ We may also argue that privatisation ought not to have been implemented as a dumping sale, since thereby, privatisation was marked by the features of a sellout and national assets were considerably devaluated. That is a matter of course, but we did not have an alternative and by way of the early launched privatisation, we markedly and initially left our former socialist rivals behind in the area of the import of capital. ${ }^{9}$ The early launch facilitated that massive privatisation in Hungary would be completed by 1996-1997, consequently, Hungarian economy became euro-conform, since the absolute predominance of private property was reified. "Soft" state property had been transformed into "hard" private property and the crucial process of the denationalisation of economy was completed. $^{10}$

${ }^{8}$ See, Stark, D.: Privatizáció Magyarországon. A tervtől a piachoz vagy a tervtől a klánig? (Privatisation in Hungary. From Planned Economy to Market Economy, or, from Planned Economy Back to Clans). Közgazdasági Szemle, 38 (1991) No. 9. It was primarily Mihály Tóth, who demonstrated that the majority of economic crime following the political transformation was committed via having recourse to state aid, which, as to its significance, is followed by bankruptcy crime, whereas, explicit privatisational crime occurred relatively rarely. Nevertheless, public opinion takes an opposing viewpoint. Otherwise, simultaneously with drafting the Act on Business Associations, specific facts of the cases of economic crime were adopted in the Penal Code. See, Tóth, M: Piacgazdaság és a büntetőjog (Market Economy and Penal Law). Magyar Jog, 42 (1995) 641-646.

9 See, Diczházi, B.: A külföldi töke szerepe a privatizációban (The Role of Foreign Capital in Privatisation). Budapest, 1997. Diczházi assesses this role basically in an affirmative manner, albeit, he naturally mentions the "colonising" investment of foreign capital with the exclusive objective of "market acquisition". Nonetheless, without foreign capital, our major companies would have gone bankrupt, which would have incurred an enormous scale of unemployment. In Hungary, restructuring the economy and modernisation of the structure of products were based on foreign capital. Obviously, adverse and negative tendencies also manifested themselves, such as the emergence of the so-called hawk-capital, etc.

${ }^{10}$ See, Karsai, G.: "Nem tudták, de tették" ("They Were not Aware of What They were Doing”), and Bager, G.: A magyar privatizáció a pénzügyi ellenőrzés szempontjából 
We distributed and plundered public property, the heritage of workers and employees, some people would repeatedly assert. But that is glaring blunder. The Hungarian state had by no means possessed a venture capital of such an extent as that which was finally privatised. Unlawful state property, i.e., the confiscated fortunes of Duke Esterházy and Uncle Schwartz were privatised, the value of which must have rather diminished than increased during the system of planned economy. Namely, a considerable part of state assets at the end of the 1980s was non-working capital. En passant, national property has not disappeared, it transformed: state property transformed into private property. In my view, the assets of Peter Kovacs' limited liability company also belong to the property of the nation, just as those of the former State Construction Company no. 43 did. The overwhelming majority of the assets deriving from foreign investment (with the exception of the dividend) also constitutes a part of the property of the nation, since foreign owners cannot transfer the hotel or the factory abroad, furthermore, they mostly employ Hungarian citizens, etc.

As to its social aspects, the process of privatisation was apparently not "mirthful". Scilicet, the task seemed almost unfeasible, or, as the statement made by the Polish Lewandowski that became an adage assessed: unpossessed assets of unknown origin needed to be sold out to buyers, who were out of funds and who, by the way, did not want to purchase the stocks of losing state companies. State property needed to be erased at a time, when the supply was many times higher than the demand. Obviously, it was managed in a paramountly contradictory modus operandi, even if we disregard errors deriving from non-preparedness and ignorance. ${ }^{11}$ According to my estimates, privatisa-

(Privatisation in Hungary from the Viewpoint of Financial Control). Both studies were published in the volume: Állami vagyon - privatizáció - gazdasági rendszerváltás (State Property-Privatisation-Economic Change of Regime). Budapest, 2005. 47-50 and 75-79. For a summary, see, Kovács, Á.-Bager, G.: Privatizáció Magyarországon (Privatisation in Hungary). 1-2, Budapest, 2004. Various economic assessments stated that the venture capital of the state in 1990 amounted to 2,400-2,500 million HUF, whereas, the number of the respective companies was 2000. Of course, no precise assessment of the assets was made. According to Ádám Török, the advance of Hungary in re transformation achieved at the beginning of the 1990s "could be attributed to more speedily implemented economic and legal reorganisation, to privatisation based on market relations that by large relinquished distribution techniques, to its favourable judgement in terms of international politics and to its auspicious geographical position." Gazdaság Kelet-Közép-Európában 1990-2006 (Economy in Central-Eastern-Europe between 1990-2006). História, 29 (2007) No. 4.

${ }^{11}$ See further, Voszka, É.: A privatizáció tizenöt éve és jövője (One and a Half Decades and the Future of Privatisation), and Az Állami vagyon - privatizáció - gazdasági 
tion in Hungary approached the optimum attainable under the prevailing conditions up to a rate of three quarters, nevertheless, it must have offended the sense of justice of the society, since those who were in advantageous positions came off well. What must be recorded as the greatest achievement is that institutional privatisation could be completed so that we took second place subsequently to the Germans, thereby, we were past privatisation entailed by the political transformation. ${ }^{12}$ Following 1998, the issues under consideration related to privatisation in Hungary were already "bourgeois" issues, scilicet, we faced the following alternative: we either sustain a relatively powerful public sector with the decisive predominance of private property, like Austria and France, where besides public utility companies, the so-called strategic companies and associations that generate profit for the state coexist, or, we opt for the liberal way, which is characteristic of Scandinavia and the Benelux states, where merely the literally public utility companies are state-owned. In my view, the decision between the two approaches is dependant on the performance of the state: if we are able to positively regulate, supervise and enforce compliance with the rules, conclude privatisation agreements safeguarded by adequate guarantees and de facto enforce these guarantees, then state property can be minimised, indeed. If, however, the regulation has loopholes, the agreements contain defaults and public administration can be corrupted, we will be better off with a more extensive state sector. This, however, is an issue of the actual economic policy, not of the change of regime. ${ }^{13}$

rendszerváltás (State Property-Privatisation-Economic Change of Regime). Budapest, 2005, 36-37.

12 János Kornai qualified privatisation too accelerated as early as in 1989 and challenged its undervalued implementation. See, Kornai, J.: Indulatos röpirat a gazdasági átmenet ügyében (A Vehement Pamphlet in the Matter of Economic Transition). Budapest, 1989. He upheld his viewpoint in his volume of studies: Szocializmus, kapitalizmus, demokrácia és rendszerváltás (Socialism, Capitalism, Democracy and the Change of Regime). He advised against "shock-therapy via privatisation" and deemed the rate of transformation to be out of measure (77-78). As for my view, I don't share his opinion: I contend that privatisation needed to be accomplished and stable property relations needed to be established the sooner the better, which, as a matter of course, entailed economic and social sacrifices.

${ }^{13}$ Foreign special literature generally considered privatisation in Hungary to be highly successful, whereas, in Hungary, it rather met criticism. Certainly, privatisation that meets general satisfaction is impossible, undoubtedly, there have been erroneous dicisions, e.g., the process of privatisation lacked environmental audit for a long time and aspects of competition policy were also disregarded. Nonetheless, privatisation averted massive unemployment and the great majority of privatised companies proved to be operative in the long-run. 
3. The denationalisation of Hungarian economy with respect to the proprietary structure substituted for the primitive accumulation of capital, which had undergone in Western-Europe a couple of centuries before. A great proportion of the private companies of Hungarian new-capitalism needed to originate in state property, since otherwise they could not have been established. Privatisation was substantiated by Hungarian business law drafted parallelly, which guaranteed an operative legal framework for the termination of the dominance of state property and for the formation and consolidation of market economy based on competition and private property. The criticisms that the statutes pertaining to privatisation were not faultless and that the application of the pertinent law was severely inconsistent are well-founded, but on the one hand, this could not be otherwise, since we were not following a beaten track, on the other hand, these faults remained within tolerable limits in comparison with other former socialist states. The faults were inevitable, since we were dealing with unfamiliar legal techniques, improvisation was necessary, and generally, legal regulation was formulated without the necessary economic bases, in defiance of significant political resistance and social-economic tensions. In this status quo, according to my view, the primary factor was that institutional privatisation was relatively rapidly implemented within the available legal framework. With reference to the title of a famous Italian film: privatisation has been accomplished, it's time to forget about it.

The most severe criticism vis-a-vis law-making pertaining to privatisation (mainly in re the phase encompassing 1988-1990) was that it substantiated "the salvage of power by communists", thereby, it thwarted a substantive political transformation. We will dwell upon that circumstantially later. Now we restrict ourselves to noting that interim sociological research conducted primarily by Tamás Kolosi and Erzsébet Szalai have elucidated that the top-level partyleadership of the Kádár-regime and the party-workers hardly acquired any property via privatisation. ${ }^{14}$ However, it was principally the (40-50-year-old) younger technocracy of the twilight of the Kádár-era, crucially the high- and middle-level management of companies and the economic leadership of the state apparatus that did acquire property. They, while cooperating with foreign capital and relying on the actors of Hungarian small-scale industry, of private trade and on small ventures, could become capitalists or retain their positions in the management as well as accede to further management positions. Disregarding some leading figures of the Alliance of Young Communists, we could hardly mention explicit party-workers among Hungarian major

${ }^{14}$ See, Szalai, E.: Gazdasági elit és társadalom a magyarországi újkapitalizmusban (Economic Elite and Society in the New-Capitalism of Hungary). Budapest, 2001. 37-41. 
entrepreneurs and top managers. Of couse, the stratum of these technocrats and managers belonged to the nomenclature of the Kádár-regime, so far as they were accidentally also party-members, or, if they were independent, filling their positions was dependant on the consent of the respective party-organ. Nevertheless, this is valid with respect to the great majority of the so-called bourgeois political elite of the era following 1990, as well. In case of a peaceful transition and an evolutionary change of regime, which marked the Hungarian transformation, it was almost inevitable that the stratum of younger technocrats and managers, which was acknowledged by the West, spoke foreign languages and was familiar with the sciences of Western business management and organisation, could the most exploit the potentials of privatisation. The respective individuals can be only vaguely considered post-communists by reason of the recollection of their past, they are de facto new-capitalists or new capitalist managers. As to my view, "the real winners" of privatisation in Hungary were firstly, the foreign capital, especially major multi-national companies, secondly, former Hungarian company-management and the technocrat bureaucracy consisting of the economic leaders of the socialist state, thirdly, small-scale entrepreneurs possessing some capital (small-scale industry, retailers, workteam associations, complementary workshops of agricultural cooperatives), however, by no means the party-bureaucracy of the Kádár-regime. Which, I assume, in case of an evolutionary (and non-revolutionary) change of regime, was a nearly logical consequence of the Kádár-era in re its so-called goulash communism and soft dictatorship.

Could the transition have taken another track? Perhaps, we could have allocated company assets, stocks among people, which would have resulted in people's stock-socialism instead of capitalism. People arguing for that are not aware of the basic realities of international politics, world-economy or of Hungary. ${ }^{15}$ What we need to add on the basis of the research of György Matolcsy and Péter Mihályi ${ }^{16}$ is that contrary to fallacies, the redistribution of state property was not principally implemented via privatisation and the application of the law concerning privatisation, but implicitly, via long-standing high

\footnotetext{
${ }^{15}$ Sándor Kopátsy "contends" that state property should have been allocated among people. See, A magyar privatizáció stratégiája (The Strategy of Privatisation in Hungary). Central European Time, 1998. No. 6-7. 45-53. Cf., A comprehensive essay on the potentials of "democratic privatisation": Mocsáry, J.: A dolgozói tulajdon Magyarországon. Múlt, jelen, jövö. A munkavállalói résztulajdon problémája (The Property of Employees in Hungary-Past, Present and Future-The Problem of the Employees' Share), Budapest, 1998.

${ }^{16}$ See, Matolcsy, Gy.: Emlékeim a privatizációról (My Recollections of Privatisation). Central European Time, 1998. No. 6-7. 7-8., and Mihályi: op. cit. 125-130.
} 
inflation, import-liberalisation, exchange-rate policies, bankruptcy waves, etc. Privatisation from the outset, undoubtedly also as an aftermath of the communication of the media, had become "the black sheep" of the change of regime, the scapegoat originating in the unfair and unethical enrichment of some, which appalled masses of people. We cannot assume that without privatisation we would have realised a form of capitalism that lacked rich people and capitalists.

Observing the political conflicts that have increasingly unravelled following the mid-' $90 \mathrm{~s}$ and that the outraging passions related to the change of regime have not abated, but have led to scenes of civil war in Hungary, many basically contend that some strata of the society realised as late as the end of the 1990s that the broadly construed privatisation, which substituted the primitive accumulation of capital, had been accomplished and the new bourgeoisie had emerged, therefore, the structure of the social elite could be exclusively modified by the seizure of the acquired property of "winners". In Spain and Portugal, the change of regime, which followed a fascist establishment structure, did not take the character of property acquisition, whereas, in former socialist states it did. Subsequently, "the losers" of the change of regime can merely acquire property by taking it away from "the winners". The consequentially emerging political slogan has been that we demand a new, real change of regime and need to square accounts finally with the post-communist elite that had salvaged its power. For some, redistribution would imply a dream come true, however, a change of regime in the property structure cannot be implemented and "bad capitalists" cannot be replaced for "good capitalists" within the system of capitalism every 20 years. ${ }^{17}$ Such a replacement can at most be effected by the market via its intangible instruments.

4. Privatisation in Hungary commenced essentially spontaneously, since we were not swept into privatisation by a central decision of the state, but by taxremitting and organisational restructuring transactions of the managers of major companies and by the improvisational utilisation of the power-vacuums that gave way after such transactions. Namely, the idea of privatisation had not even emerged during the drafting of Act 6 of 1988 on Business Associations (hereinafter: ABA).

The so-called spontaneous privatisation was received by inconceivably relentless criticism in Hungarian social science literature. According to Rudolf Tökés, during the settlement of political problems, the communist elite transformed state-owned companies into management-owned ones and by

${ }^{17}$ See also, Kulcsár, K.: Az új politikai rendszer és a magyar valóság (The New Political System and Hungarian Reality). Budapest, 2006. 27. 
exploiting defects in law, the inner circle of the managing elite fraudulently peculated via unfair profits the joint ventures established with the participation of Western investors. Concurrent business law facilitated the self-privatisation of state property, therefore, "artful vigilants" with appropriate relations could become billionaires. ${ }^{18}$ As Sándor Kopátsy formulates: "The policy, as a consequence of which state property was consigned primarily to foreign ownership, so that at the same time an incredibly large domestic state-debt was generated and some have made revolting fortunes, while two-thirds of the population today live at a substantially lower standard and more hopelessly than they did in the final decade of the failed socialist regime, is to be considered a crime against the Hungarian society." ${ }^{19}$ According to Tamás Fricz, the elite of the former party-state and the members of its nomenclature enjoyed the benefits of spontaneous privatisation and therefore, “...the transition to market, or, if you please, capitalist relations had been implemented by the political and economic elite of the Kádár-regime in Hungary, wherefore, the economic leaders of state socialism became the managers of capitalist private property." 20

At the same time, as Éva Voszka claims, in our days it is unequivocal that facts contradict "the frustrated political charge that the nomenclature has salvaged itself". "Furthermore, Péter Mihályi expressly states that spontaneous privatisation is "the most deceptive term" for the description of privatisation in Hungary. ${ }^{22}$ Its principal purpose is the pursuit of a publicity campaign against non-fellow post-communists, the grudging lament of those left without fortune, which goes under the slogan: "my state property is just being misappropriated by others, unfortunately, not by me". However, as Árpád Kovács clearly demonstrated on the basis of the examinations of the State Audit Office, the decisive majority of the transactions related to privatisation in 1989-1990 had been lawful. ${ }^{23}$

Nevertheless, we should observe the facts. Act 28 of 1987 permitted that expressly domestic legal entities, that is, state-owned companies established joint-stock companies or limited liability companies pursuant to the Commercial Code of 1875 , whereas, the Ministry of Finance guaranteed quite significant

${ }^{18}$ See, Tőkés, R.: A kialkudott forradalom (The Haggled Revolution). Budapest, 1998. 345-384.

${ }^{19}$ See, Kopátsy: A magyar privatizáció stratégiája. op. cit. 47.

${ }^{20}$ See, Fricz, T.: Az árok két oldalán (On Opposite Sides of the Ditch). Budapest, 2006. 68.

${ }^{21}$ See, Voszka, É.: Spontán privatizáció Magyarországon (Spontaneous Privatisation in Hungary). Budapest, 1998. 137.

${ }^{22}$ Cf., Mihályi: op. cit. 98.

${ }^{23}$ Cf., Kovács, Á.: Számvetés a számvetésről (An Account on Accounts). Kurtán, S.Sándor, P-Vass, L. (ed.): Magyarország évtizedkönyve. Budapest, 1998. 197. 
profit tax-allowances for new commercial associations for three years under new taxation law. At the initiation of the management of Medicor and Ganz Danubius companies, the management of major companies launched the transformation of the factory units of the companies into associations and of these corporate centres into holdings for asset administration. Thereby, they did not intend to privatise these companies, but endeavoured partly to gain taxallowances in the interest of their liquidity and partly to modernise the internal organisational and operational mechanisms of the companies according to Western models. Therefore, this "internal reorganisation into associations" had ensued before the adoption of ABA (and since the Commercial Code of 1875 stipulated more liberal rules than the future $\mathrm{ABA}$, the management of major companies had positively endeavoured to take action before ABA took effect on $1^{\text {st }}$ January, 1989 as the data of the Registry Court clearly demonstrate!). Besides, these transactions implied at most de jure privatisation, scilicet, they can be merely described as "pseudo-privatisation" as Mária Móra formulated as early as in $1991 .^{24}$

Before the spring of 1989 , the management of major companies had essentially intended to rationalise, not to privatise, since financial regulations expressly motivated them to proceed so. Therefore, the transactions of 19871988 can at most be assessed as the non-conscious preparation of privatisation, in substance, however, these had been financial-organisational routine operations. ${ }^{25}$ During the spring of 1989 , when it could be anticipated that the political transformation was well within reach, the management of major companies united in the Hungarian Economic Chamber elaborated the conception of privatisation, the purpose of which consisted in the subjection of the established associations to "partial" privatisation. The scope of this partial privatisation encompassed: $a$ ) so much as possible, the involvement of foreign and professional minority investors, which could potentially effect capital increase, and thereby, the acquisition of surplus capital, $b$ ) clearance of the debts of the respective companies via the transfer of debts to the state in return for shares and via the conversion of bank liabilities to stocks, $c$ ) the nomination of the management of companies (and to a smaller extent of employees via employee stocks) to joint proprietors, $d$ ) the conveyance of "left-over" stocks to partner companies,

${ }^{24} C f$., Móra, M.: Az állami vállalatok (ál)privatizációja [The (Pseudo-)Privatisation of State-Owned Companies]. Közgazdasági Szemle, 38 (1991) No. 6.

${ }^{25}$ Cf., Mihályi, P.: A gazdaság államtalanítása 1988-1998 (The Denationalisation of Economy between 1988-1998). In: Kurtán-Sándor-Vass (ed.): Magyarország évtizedkönyve, op. cit. 164. 
so that companies and banks assisted one another by cross shares in the implementation of privatisation.

In essence, this conception drew on the system of the self-governance of companies introduced in the state sector in 1984. A contributor to the elaboration of the conception, Ádám Angyal explicitly contended that in 1990, the state property in companies was at most 20 p.c, which was equivalent to the starting capital that the state allocated to companies upon the introduction of corporate governance. The so-called self-governing companies managed by boards of directors were de facto no longer state companies and the companies themselves needed to decide voluntarily on their transformation into associations and on privatisation. If privatisation did ensue, managers and employees were due proprietors' shares. The state could also privatise companies under so-called state-management, in which state property equalled at least 20 p.c., whereas, it could merely exercise supervision over the privatisation of selfgoverning state companies via public authority instruments and could receive cca. 20 p.c. of the revenues deriving from privatisation. If we view this conception objectively, it by no means implied spontaneous privatisation within the scope of self-governing-self-managing state companies, but voluntary and decentralised privatisation based on the decision of the company reached in the spirit of corporate autonomy pursuant to State Company Act (Act 6 of 1977 as amended in 1984).

Concurrently with the elaboration of this conception in 1989, the resourceful researchers of the Financial Research Share Company, mainly under the leadership of György Matolcsy, launched the so-called privatisation of noncapital contribution and various company evacuation and redoubling transactions. ${ }^{26}$ In many cases, these did not mean privatisation and promoted the foreclosure of the law pertaining to the privatisation of small businesses, nevertheless, by reason of the absurdities of capital assessment, they necessarily involved the possibility of abuse. Therefore, law-making needed to partly guarantee the state control over acts of partial privatisation (e.g., sales of real estates), partly draft the regulation of the reorganisation of state-owned companies into associations.

The conception of the management of major companies was by that time opposed by the aligning ideologists of central economic management, such as The Office of Economic Planning, the financial portfolio, the central issueing bank and by reputed reform economists-in a peculiar manner, all of them-rew

\footnotetext{
${ }^{26}$ György Matolcsy argued for voluntary company privatisation in several articles in 1989-90. Cf., e.g., Matolcsy, Gy.: A spontán tulajdonreform védelmében (In Defence of Spontaneous Property Reform). Külgazdaság, 35 (1990) No. 3.
} 
on the (Stalinist) political doctrine of the unified and indivisible state property. Actually, real financial reasons accounted for the intervention: the privatisated equivalent could not remain in the property of companies by reason of impending insolvency. Therefore, the self-privatisation of companies needed to be prevented. Nonetheless, as it was manifest in former documents of the Financial Research Institute, they had no actual conceptions either concerning the required manner of the reorganisation of state-owned companies into associations, or concerning the structure of state ownership to be established. ${ }^{27}$ Besides, state-controlled privatisation, as the pertinent law of 1992 demonstrates, could have been launched exclusively via the dissolution of corporate governance and management. However, the express declaration of this was shunned both by government commissioners entrusted with the task (István Tömpe and János Martonyi) and by their theoretical supporters (László Antal on the part of the Secretariat of Economic Policy of the Council of Ministers), György Surányi (under-secretary of state at the National Planning Office) and Lajos Bokros (Hungarian National Bank). Their disposition was prudent, since corporate governance had considerable social support. ${ }^{28}$

In this situation, the leadership of the Ministry of Justice with the support of the concurrent Prime Minister, Miklós Németh decided that while maintaining the prevailing corporate governance and management, it would amend the State Company Act, so that the voluntary privatisation of state-owned companies dependant on the decision of the company would be permitted under increased state control within the purview of a unified, market-oriented Act on Reorganisation. Thereby, law-making resigned the coercive transformation of companies (as Kálmán Kulcsár in his ministerial statement emphatically asserted: the pertinent law concerns reorganisation, not transformation), therefore, the decision on reorganisation at companies under state control was to be made by central organs of state administration, whereas, at self-governing and selfmanaging companies, the decision on reorganisation lay with corporate organs. The respective statute also established a legal technique of transformation, which did not necessitate two-graded privatisation, since reorganisation could

${ }^{27} C f$., Lengyel, L. (ed.): A tulajdon reformja (Property Reform). Pénzügykutató Rt., Budapest, 1988. Csillag, I. (ed.): A társasági törvény, a tulajdonreform és az átalakulás kérdései (The Act on Business Associations, Property Reform and Issues of the Transformation). Budapest, 1988.

${ }^{28}$ We must note that the conception of corporate management started to gain ground in the Soviet Union at that time. See, Pethö, R.: Törvény a Szovjetunióban a dolgozói kollektívákról (Law Pertaining to Employees' Collectives in the Soviet Union). Magyar Jog, 34 (1987) No. 1. This also provided political support to the backers of corporate autonomy. 
simultaneously constitute a process of privatisation. Therefore, the Act on Reorganisation was based on the maintenance of the former status quo.

Furthermore, Act 13 of 1989 on Reorganisation (hereinafter: AR) established complicated distribution rules and intended to grant a share to each party. These rules were designed to be experimental by the law-maker (it prescribed a revision after two years), furthermore, it made the majority of rules optional, namely, it was facilitated that the state holding organ and the company agreed on different rules within a specific term. The modus vivendi is well-demonstrated by the regulations below:

- the prerequisite of reorganisation was capital increase (outsider investors needed to increase the value of company assets at least by 20 p.c. or by 100 million HUF, therefore, the involvement of outsider investors was required, so that pseudo-privatisation could be precluded),

- 20 p.c. of the company assets calculated on the basis of the balance sheet belonged to the state (the state holding organisation),

- so that the financial basis of local governments to be formed could be secured, on grounds of the location of the estate, the respective local council (following 1990, the local government) was due an associational share equivalent to the value of the inner settlement estates as listed in the company balance sheet (obviously, the full value was to be considered and not the value decreased by company liabilities, as the State Property Agency endeavoured to interpret it later in the interest of the increase of central state revenues),

- the issuance of employees' stocks for employees was obligatory at a value of up to 10 p.c. of the capital stock of the association,

- the rest of the assets could be sold to outsider investors, so that 80 p.c. of the equivalent revenues were due to the state holding organ and 20 p.c. could be retained by the company within the scope of assets beyond the capital stock (the so-called privatisational equivalent quota: PEQ),

- the association share that could not be sold could be retained by the association as a so-called own share. ${ }^{29}$

I dwelt on the above more circumstantially, because these amply demonstrate the desperate attempt of the law-maker to temper people's moods in the spirit

${ }^{29}$ Concerning the Act on Reorganisation, see, Sárközy, T.: Egy törvény védelmében III. (In Defence of an Act: Parts 1-2). Figyelö, 1989. When I generalised the conception unfolding in AR, I was considering such a plural proprietary structure, in which not only the property of business associations, but also the self-managing property and settlement assets have a role. See, Sárközy, T.: A tulajdonreformról a társasági törvény után (On Property Reform Following the Act on Business Associations). Budapest, 1989. 
of the principle of "live and let live", so that each party received a share. Nevertheless, by the spring and summer of 1989 , people had the impulsion to come to grips, all of them wished to dispose of the whole of the property. Although, the emphasis on the technical features of AR indignified all, AR was not challenged by reason of the fact that it accomplished a covert property reform, on the contrary, it was impugned, since it did not implement the property reform, which would have favoured its critics. As Kálmán Kulcsár stated in the introduction of the act, the starting point of AR was the prevailing status quo and "it did not even by an inch increase the formerly guaranteed entitlements of companies to dispose of property" (but it did not reduce them, either).

The attack against AR was led by Lajos Bokros on the part of the reform circles of the Hungarian Socialist Workers' Party, who, while undimensionally exaggerated the problem, described spontaneous privatisation as a dead end of the complete change of regime. He further dared the absurd statement that "the elite of corporate and economic management" (?) and "the ambitious new elite" reached a modus vivendi on the acquisition of public property disregarding the majority of society, ${ }^{30}$ albeit, as György Szoboszlai correctly stated concerning the so-called decentralised privatisation, basically, the battle between the "old" apparatus of economic management and the "old" corporate management was at issue, ${ }^{31}$ in which the bourgeois opposition got involved primarily by reason of the elections. ${ }^{32}$

Nevertheless, political attack was unvariably directed against AR, albeit, beyond estate manipulations, 95 p.c. of the cases that presumably involved abuse occurred via the application of the Commercial Code or ABA. The mere protraction of the concurrent proceedings of the Registry Court did not allow for considerable pre-election abuses via the implementation of AR, which took effect on $1^{\text {st }}$ July, 1989. Furthermore, by January 1990, pursuant to Acts 7 and 8 of 1990, the State Property Agency, a special publicly financed organ established for the management of state property as a Hungarian Treuhand was

${ }^{30}$ See, Bokros, L.: Rendszerváltás vakvágányon (The Change of Regime on Tail Track). In: Kurtán, S.-Sándor, P.-Vass, L. (ed.): Magyarország politikai évkönyve. Budapest, 1990. 72-78.

${ }^{31}$ Cf., Szoboszlai, Gy.: A rendszerváltás jogállama (The State Founded on the Rule of Law during the Change of Regime), in the collection of studies: Bayer, J.-Kovch, I. (szerk.): A kritikus leltár. A rendszerváltás másfél évtizede (A Critical Inventory). Budapest, 2005. 24.

${ }^{32}$ See, Tökés, R.: "For the purposes of their campaigns, both the Hungarian Democrats' Forum and the Alliance of Free Democrats opposed that the insider management elite misappropriated the state-owned industrial, commercial and supplier companies by way of privatisation.” In: Tőkés: op. cit. 384. 
finally founded, furthermore, state control over acts of privatisation construed in a broader scope effected by corporate governance and management (such as estate transactions, contributions in kind, etc.) was also established (obligatory registration, authorisation and the right of veto, etc.). Albeit, certain partial elements failed, such as a market-based act on accountancy for the purposes of the assessment of assets, we can assert that by the spring of 1990, the institutional system of voluntary, decentralised and state controlled privatisation based on corporate decisions had been established in Hungary, which, according to my opinion, would have been completely operative in Hungary within a few years. Assumably, Hungary would have been the only CentralEastern-European country (in other former socialist countries, in the absence of corporate autonomy from the outset, merely centralised, state-controlled privatisation could be implemented), in which by reason of the institutionalisation of corporate governance and management in the mid-1980s, such a form of privatisation could have been accomplished, which would have been based on the primacy of voluntary and decentralised privatisation in case of mediumand smaller-scale companies. Crucial companies of strategic importance, which were by all means or could have been controlled by state administration, would have been privatised by the state, whereas, the "self-privatisation" of smalland medium-scale companies could have been subjected to proper legality control by the state.

5. This solution was not implemented, which had several political and economic reasons. One of these was the inordinate defamation of decentralised privatisation based on corporate decisions by the mass media and public sentiment and its substantive identification with crime, abuse and communist salvage of power. The other reason was that the circle of the supporters of bourgeois parties that had got into power could be assigned to positions in the economic management merely via interventions by central state administration, which was unfeasible at companies, therefore, privatisation needed to be centralised by the state. Actually, privatisation based on corporate decisions did favour company management and the employees of more profitable companies with greater economic power vis-a-vis other strata of society, such as civil servants, retired or young people.

Such a privilege of those in advantageous positions was unacceptable for a considerable part of the society, disregarding the fact, that decentralised privatisation would have precluded reprivatisation and infringed the interests of "the losers" of socialist nationalisations. (It is another issue that compensation finally did not occur, nevertheless, those concerned had not known that at that phase.) The apparatus of the organs of economic management also 
appreciated their transfer from positions in "normal public administration" to much more yielding positions created at privatisational organs.

On the other hand, corporate governance can function as an organic part of democratic socialism, nevertheless, it is inevitably anacronistic in a consistent capitalist system. Namely, corporate governance was simply nonsense for Western investors (this was even more manifest in Yugoslavia and its successor states). This corporate structure could accommodate only those professional investors that had had long-standing commercial-cooperational relations with the companies of the socialist states, whereas, it deterred financial investors. Major Western banks and multinational companies (and the adjacent gigantic audit-counselling concerns, major law firms) intended to negotiate with the state itself, but not with corporate management. Apparently, by reason of the enormous domestic and foreign state debts, Government did not intend to share the privatisational equivalent with any party, not in the least degree with corporate management, thereby, it demanded the complete revenue deriving from privatisation for itself. Such a disposition of the then Government was strongly supported by the International Monetary Fund and the World Bank.

At the same time, decentralised privatisation described as spontaneous underwent de facto in such a small scale that if communists had based their power on that, the successor party could have hardly won the elections in 1994. Therefore, the communist salvage of power based on spontaneous privatisation is mere fiction. Unequivocal data supplied by György Matolcsy, Éva Voszka and Péter Mihályi show that at most 2 p.c. of the venture capital of the state that could be privatised was affected by a legal form of privatisation based on company decisions (at cca. 150 companies). ${ }^{33}$ Mihályi further adds that "considering their proportions, negative examples between 1988-1990 had been not more numerous than between 1990-1992 or in any subsequent three years' period." ${ }^{34}$

Did abuses occur? Yes, they did, however,

a) they were not committed on grounds of $A R$,

b) it was ABA that substantiated the abuses, nevertheless, if ABA had not been in force, the number and scale of abuses would have been even greater pursuant to the Commercial Code of 1875 . The majority of presumed abuses were associated with the privatisation of contributions in kind and company

${ }^{33}$ See, Matolcsy, Gy.: Lábadozásunk évei (The Years of Our Convalescence). Budapest, 1991. 227-229., Voszka, É.: Spontán privatizáció Magyarországon (Spontaneous Privatisation in Hungary). Budapest, 1998. 130-145., Mihályi, P.: A magyar privatizáció krónikája. op. cit. 98-102.

${ }^{34}$ Cf., Mihályi: A magyar privatizáció krónikája. op. cit. 100. 
evacuation, not with general privatisation, but with those transactions affecting retail industry and catering trade companies concentrated in co-operatives that preceded Act 76 of 1990 on the Privatisation of Commercial, Service, Hotel and Catering Businesses [the so-called Act on Small (Pre-)Privatisation]. ${ }^{35}$ Another area of abuse was constituted by matters related to the assets of the Communist Party (Hungarian Socialist Workers' Party) and of the associated social organisations (such as the Alliance of Young Communists and the Alliance of Pioneers), which, however, were beyond the scope of legislation concerning privatisation by the state. (The issue of the assets of the Communist Party designated to be inherited by the Hungarian Socialist Party had been transferred to the political portfolio during the so-called Round-Table-Negotiations, which had paved the way for the political transformation, therefore, it was not dealt with during the codification of business law.)

As a matter of course, objective assessments of the spontaneous (decentralised) privatisation were written as early as in the 1990s, as well. György Matolcsy, the under-secretary of state responsible for economic-policy under the Antall-Government formulated the followings: "Spontaneous privatisation belongs to the heritage of the Hungarian path. It is the logical product of selfdestruction and the result of a permissive policy in lieu of aggression. Its spontaneous character was rendered by the fact that it was the corporate management that initiated reorganisation and riddance from state property. Of course, this entailed the salvage of former positions, which was the specific way of escape. The real import of spontaneous privatisation consisted in the fact that it prepared real privatisation." 36 According to Matolcsy, the minor amendments of former law effected by the Antall-Government in the summer of 1990 were designed to soothe the mood and temper of the new parties in Government: "Eventually, the amendments did not modify substantially the legal framework of privatisation. Although, they reinforced the state control of privatisation and guaranteed the state more powerful influence on privatisation, they did not rechannel former processes or obstruct former paths. ${ }^{, 37} \mathrm{~A}$ similarly objective assessment was rendered by Tibor Pongrácz, the political under-secretary of state of the Antall-Government (and the Chairman of the

\footnotetext{
${ }^{35}$ The draft of the Act on Small (Pre-)Privatisation was ready in the autumn of 1989, but according to the demand of the parties in opposition, it was only adopted by Government presided by József Antall. In the meantime, the number of businesses to be privatised had decreased by several thousand, since the practical ones had taken action, before the act took effect.

${ }^{36}$ See, Matolcsy, Lábadozásunk évei. op. cit. 27.

${ }^{37}$ See, ibid. 103.
} 
Board of Directors of the Hungarian Privatisation and State Holding Company in 1997), albeit, he exaggerated the scale of spontaneous privatisation: "These statutes adopted in 1988 and 1989 ... (ABA and AR, sic) ... did actually guarantee the most consequential prerequisite of bourgeois transformation, since they legitimised private enterprises and did not restrict foreign investment. Nevertheless, they did not provide for the protection of state property and no parallel law pertaining to the protection of assets related to privatisation was drafted." Pongrácz is correct, however, the time for parallel law-making was very limited. But we should follow the train of thought of Pongrácz: "Therefore, the opposition assumed that the purposes of the pertinent statutes were the salvage of power, i.e., the conversion of political power into economic power. We allow that in the period of spontaneous privatisation many unethical and perhaps legally contestable cases occurred, therefore, we can rightly condemn it. Nonetheless, if we view the process in its completeness and from a historical perspective, we can affirm a great deal of it, since what already within the framework of the communist regime did commence were the establishment of private enterprises, the deconstruction of unprofitable and futureless state property and the irreversible conversion to real market economy... For the former elite that had abandoned its political and economic positions, such gaining ground by entrepreneurs, which ensued in many waves, opened up opportunities for escape and according to some experts, that explains why the former elite did not even consider violent intervention against the change of regime." 38

6. Subsequently to the free elections in the spring of 1990 and the formation of the centre-right Antall-Government, minor legal amendments were effected and for some time, the basically self-initiated decentralised privatisation of companies continued, although, governmental control was more powerful and the active involvement of the State Property Agency into privatisation also increased. Act 76 of 1990 on privatisation in commerce and catering trade (the so-called Act on Small (Pre-)Privatisation) was promulgated. For some time, under the changed political circumstances, the management of companies seemed to acknowledge the increase of the power of the State Property Agency and agreed on a modus vivendi with its leadership, according to which, Ferenc Mádl, a minister without a portfolio supervised privatisation, his deputy was János Martonyi (the former government commissioner of the Németh-Government responsible for privatisation), whereas, the managing director of the State

\footnotetext{
${ }^{38}$ Pongrácz, T.: Privatizáció és kárpótlás (Privatisation and Compensation). In: Magyarország a XX. században (Hungary in the 20 Century), Vol. 3., Szekszárd, 1997. 678-682.
} 
Property Agency was Lajos Csepi, a director of the former Price Control Authority. In this respect, Erzsébet Szalai notes correctly that the so-called Kupa-Programme actually acquiesced in decentralised privatisation. ${ }^{39}$ At the same time, Buyout by Corporate Management combined with the so-called Employees' Share Scheme had a growing significance, the latter of which was politically supported by government parties, as well. ${ }^{40}$ Although, the so-called Government Theses titled "Property and Privatisation" written by Bertalan Diczházi and György Matolcsy in August, 1990 in principle objected to spontaneous privatisation and corporate governance, it reprehended privatisational "shock-therapy" and intended to provide a wide range of property for investors. According to the Theses, "the first wave" of privatisation would consist in active privatisation implemented by the State Property Agency, the second wave of privatisation would be launched by companies, whereas, the third wave would have been a peculiar take-over, when outsider investors could have contested the insider corporate management. Nevertheless, the latter alternative was not realised. Meanwhile, Act 76 of 1990 was being implemented and the considerable merits of the statute, disregarding all its contradictions, included that by cca. 1994, almost the entire segment of retail and catering trades had been transferred into private property and the majority was held by Hungarian individual proprietors, furthermore, the act had been implemented not by way of distribution, but in an open framework of market-based competition. ${ }^{41}$ Nevertheless, since the removal of former corporate management had failed in the summer and autumn of 1990, a political decision was made in 1992 on the liquidation of corporate governance and management at state-owned companies, therefore, the coercive transformation of these companies was to be effected pursuant to Acts 53-54-55 of 1992. Furthermore, in 199293, the financial empowerment of political supporters was an increasing endeavour, which manifested itself in Small Investment and Existential-Credit

${ }^{39}$ See, Szalai, E.: Gazdasági elit és társadalom a magyarországi újkapitalizmusban. op. cit. 79-80. Mihály Kupa as the Minister of Finance of the Antall-Government propagated this as a programme of economic-policy at the turn of 1990/1991.

${ }^{40}$ See, Boda, D.-Neumann, L.: MRP és MBO a hazai privatizációban ("Employees' Share Scheme and Buyout by Corporate Management Programmes in Hungarian Privatisation"), Budapest, 1998. 69-81.; Karsai, J.: Management Buyout külföldön és itthon (Management Buyout in Hungary and Abroad). Külgazdaság, 37 (1993) No. 2.; Boda, D.Hovorka, J.-Neumann, L.: A munkavállalók, mint a privatizált vállalatok új tulajdonosai (Employees as New Proprietors of Privatised Companies). Közgazdasági Szemle, 41 (1994) 1084-1096.

${ }^{41}$ See, Karsai, G.: A fogyasztási cikk kereskedelem privatizációja (Privatisation of the Retail of Consumer Goods), Budapest, 1993. 
Programmes, etc. In 1992, a separate statute, Act 44 of 1992 on the Employees' Share Scheme was enacted, which was based on the principles of the American ESOP Programme (Employees' Stock Ownership Programme). ${ }^{42}$

7. In 1992, three pertinent statutes were adopted, such as Act 53 of 1992 on the Management and Utilisation of Venture Capital to Be Retained in LongTerm State Ownership, Act 54 of 1992 on the Sale, Utilisation and Protection of Provisionally State-Owned Assets and Act 55 of 1992 on the Promulgation of Acts 53 and 54 of 1992 and on Consequential Legal Amendments. ${ }^{43}$

In this legal framework (the drafting of which was supervised by Béla Bártfai), the basically new element was rendered under the act on venture capital to be retained in state property for a long term, within the purview of which, state-owned companies as institutions were dissolved via their reorganisation into business associations and the persisting state-owned companies were also obligated to operate as business associations (the overwhelming majority of them as joint-stock companies and less than 10 p.c. as limited liability companies). Pursuant to the act, a market-conform management-system was applied at persisting state-owned companies, i.e., these business associations were subordinated to the State Holding Company (Limited by Shares). The State Holding Company functioned as the one-entity joint-stock company of Government.

The underlying conception was the unlimited nature of the power of the state as a proprietor: Accordingly, state-owned companies are the objects of state property, therefore, they neither have rights, nor earning assets (in a departing manner from the former regulation) vis-a-vis the proprietor. These statutes generally refer to venture capital, never to companies, therefore, the guarantees of corporate governance and management and of autonomy established back in 1977 were eliminated.

Neither the venture capital of the state was precisely defined, in the same manner, nor the scope of the companies to be retained in long-term state ownership were itemised, although, Article 2 of Act 53 of 1992 specified some

\footnotetext{
${ }^{42}$ Concerning the Programme titled "Kisbefektetőket a tőzsdére mindenáron" ("Small Investors to the Stock Exchange at All Costs"), announced in 1992, see, Korányi: op. cit. 46. On the programme of "stock purchase" free of charge by small investors (practically for free, via the utilisation of compensation vouchers), see, Vanicsek, M.: Elosztásos privatizáció (Privatisation by Allocation). Budapest, 1998. 44-49. Concerning the ExistentialCredit Programme and subsidies for domestic smallholders, see, Gidai, A.: Kedvezményes privatizációs technikák (Techniques of Preferential Privatisation). Budapest, 1998. 63-66.

${ }^{43}$ For commentaries on the acts, see, Sárközy, T. (ed.): Átalakulás és a privatizáció (Reorganisation and Privatisation). Budapest, 1994.
} 
general features. On grounds of the statute, Government Decree no. 126 of 1992 (VIII. 20.) and its Supplements itemised the respective companies, scilicet, a share of cca. 35-40 p.c. of the state-owned sector, including the so-called crucial companies of the state, the inner core. An endeavour of the State Holding Company (Limited by Shares) was to shun the limitations stipulated under ABA, according to the view of Jenő Czuczai, it intended to function as a corporation under public law ( $c f$., the French model), nonetheless, this collided with effective law, furthermore, the Constitutional Court under its Decision no. 33/1993 (IV. 15.) AB also annulled the provisions of Act 53 that established unnecessary exceptions. ${ }^{44}$

Law pertaining to privatisation adopted in 1992 maintained the State Property Agency as a central organ of privatisation. Corporate governance and management was terminated at companies designed to be privatised, thereby, companies were subjected to coercive transformation into business associations. Nevertheless, privatisation was not incorporated into the process of reorganisation, as it had been in 1989, but reorganisation into an association ensued first, and only then was privatisation effected as a "sellout" by the State Property Agency: it sold the state-owned shares in business associations.

Within the purview of the above-mentioned three statutes, all the companies falling under the effect of the Company Act of 1977 dissolved between 1992-1995 with the exception of about 20-30 companies under liquidation or full settlement: state-owned companies were reorganised into associations. All this took place under state direction, and subsequently, privatisation was also subordinated exclusively to state decisions. The decisions on privatisation reached by the State Property Agency were only to a minor extent determined by normative conditions (neither had been Capital Policy Directives formulated except for one), in general, uniform solutions were applied and the absence of normative conditions were meant to be rectified by wide-scale competition procedures. Nevertheless, the further implementation of privatisation was basically and unvariably market-based, albeit, "preferential procedures" (such

\footnotetext{
${ }^{44}$ Concerning the practice of privatisation between 1992-94, see, Czuczai, J.: A magyar privatizáció alulnézetböl. Múltja, jelene, jövője (Javaslat egy új liberális gazdaságpolitikának megfelelö privatizációs jogi szervezeti-intézményei koncepcióra) [Privatisation in Hungary from the Bottom-View. Its Past-Present-Future (Proposal for a Legal Organisational-Institutional Conception of Privatisation that Conforms to New Liberal Economic Policy)]. Budapest, 1994. 29-37.
} 
as privatisational leasing as a new technique) were adopted at a growing extent. $^{45}$

The situation related to privatisation between 1992-1994 became both from political and economic points of view considerably strained. The reorganisation of companies into business associations had established the sine qua non of privatisation, however, privatisation per se advanced very slowly. The actually valuable capital was possessed by the State Holding Company (Limited by Shares), the management of which (Count Pál Teleki and Szabolcs Szekeres), having returned from the USA, intended to operate their portfolio as a real monetary holding, which provoked the anger of populist radical politicians. ${ }^{46}$ Nevertheless, populist programmes directed at "the support of little man" gave one after the other ground. The tasks of the implementation of massive privatisation, the sellout of the "inner core" (Péter Mihályi) and the conclusion of the process of institutional privatisation awaited the future socialist-liberal Government, which were substantiated by Act 39 of 1995, the so-called uniform act on privatisation.

The draft of the uniform act on privatisation in line with a number of other drafts designed to promote the work of new Government had been formulated by 1993 in the Institute of Political and Legal Sciences of the Hungarian Academy of Sciences, ${ }^{47}$ and having been adjusted to the Government Programme, they were handed over by September, 1994 by the Codification Committee consisting of István Csillag, Gábor Komáromi and Tamás Sárközy to the Minister of Finance and to Ferenc Bartha, the respective government commissioner. The state administrative negotiations concerning the draft law and the parliamentary debate of the Bill took more than half a year by reason of prevailing political conflicts and the delay was also influenced by the replacement of Ministers of Finance, i.e., of Békesi by Bokros and by the appointment of Tamás Suchmann to Minister of Privatisation. Eventually, the

${ }^{45}$ Juhász, I.-Vigh, I.: A privatizációs lízingtechnika kézikönyve (A Manual for the Technique of Privatisational Leasing). Budapest, 1993.

${ }^{46}$ See, more amply, Hoóz, T.: Az ÁV Rt. mozgási szabadsága a privatizációs törvények tükrében (The Scope for Action of the State Holding Company As Reflected by the Acts on Privatisation). Gazdaság és Jog, 1 (1993) No. 2-3.; Komlós, J.: Vezetői kivásárlás (MBO) (Management Buyout). Budapest, 1993.; Mellár, T.: Vállalati átalakulások és a privatizáció (Company Reorganisations and Privatisation). In: Bródy András ünnepi kötet (Memorial Volume Dedicated to András Bródy). Budapest, 1994. 246-268.; Voszka, É.: Az agyaglábakon álló óriás (The Giant on Clay Legs). Budapest, 1995.

${ }^{47}$ See, Sárközy, T.: Javaslat a piacgazdaságot szolgáló modern kormányzás felépítésére (Proposal for the Establishment of Modern Government Promoting Market Economy). Budapest, 1994. 
basic structure and the basic principles of the draft law could be maintained, and in the spring of 1995 , the uniform act on privatisation was adopted. ${ }^{48}$

AP also created the uniform organisation for the implementation of privatisation, namely, in the form of a joint-stock close company, the Hungarian Privatisation and State Holding Company Limited by Shares was established (hereinafter: HPSHC). Although, unequivocal detachment from government property did not ensue at that time, either, AP align with the amendment of the Act of 1995 on the Budget considerably increased the scope of the assets to be privatised and simultaneously, the coersion towards privatisation. The primary mission of HPSHC was privatisation and its secondary task consisted in the administration of assets. ${ }^{49}$ The scope of companies to be retained in long-term state ownership was already itemised under the act, their number decreased substantially. Other venture capital could merely "provisionally" fall under the category of state property, they were designated to be privatized "the sooner the better": the basic objective of AP was the acceleration of privatisation. ${ }^{50}$

AP basically regulated market privatisation, which was to be implemented in return for cash, thereby, it intended to restrict preferential and "bogus" (István Csillag) privatisation to exceptional cases. In comparison with the law of 1992, AP considerably increased the constitutional guarantees of privatisation (e.g., via the prescription of privatisational memoranda) as well as the publicity and transparency of privatisation. Accordingly, the basic privatisational technique shall unvariably be the announcement of competitions, whereas, the method shall be the conclusion of an atypical deed of sale, i.e., a privatisation agreement. ${ }^{51}$

\footnotetext{
${ }^{48}$ See, Sárközy, T.: Küzdelem a privatizációs törvény körül (Struggles Concerning the Law of Privatisation). In: Kurtán, S.-Sándor, P-Vass, L. (ed.): Magyarország Politikai Évkönyve 1994-röl (The Political Yearbook of Hungary on 1994). Budapest, 1995. 194212. See further, Mihályi, P.: A magyar privatizáció krónikája. op. cit. 199-224. For a detailed analysis of AP per se, see, Csillag I.-Komáromi, G.-Sárközy, T.: Kommentár az új privatizációs törvényhez (Commentary on the New Law Pertaining to Privatisation). Budapest, 1995.

${ }^{49}$ On the administration of assets, see, Komáromi, G.: Privatizációs technikák, vagyonkezelés (Privatisational Techniques and Property Management). In: Az új privatizációs törvény (The New Law Pertaining to Privatisation). Budapest, 1995. 138-158.; Mihályi, P.: Privatizáció és vagyonkezelés (Privatisation and Property Management). Közgazdasági Szemle, 44 (1996) No. 3.

${ }^{50}$ See, Csillag, I.: Az ÁPV Rt. vagyona és gazdálkodása (The Assets and the Management of HPSHC). In: Az új privatizációs törvény. op. cit. 98-111.

${ }^{51}$ Concerning the invitation of tenders related to privatisation and privatisation agreements, see, Wellmann, Gy. A privatizációs pályázatokkal kapcsolatos jogkérdések (Legal Issues Concerning Tenders Related to Privatisation). Gazdaság és Jog, 2 (1995) No. 12.,
} 
The position of Government and HPSHC in the issue of privatisation was unvariably Janus-faced. That consisted in the followings: on the one hand, privatisation was an interest of the state, since revenues and results were indispensable for HPSHC, on the other hand, privatisation curtailed the power of the state and shortened the term of the sustainability of HPSHC. In the recent 17 years, the so-called privatisational jacket has undoubtedly and several times meant the life-belt of the budget policies of Governments. Nevertheless, in defiance of the above, the great majority of the state sector was privatised, the so-called strategic privatisation was accomplished between 1995 and 1997. By 1998, thereby, the privatisation entailed by political transformation was concluded, ${ }^{52}$ therefore, problems related to privatisation were for the time being removed from the basic agenda of economic policy. This fact was extremely appreciated in the accession process of Hungary to the EU, since we significantly preceded the neighbouring countries. ${ }^{53}$

8. Pursuant to AP, which took effect in June, 1995, the most efficient phase of Hungarian privatisation in re sales ensued between the summers of 1995 and 1996. As an irreversible process, the privatisation of the "inner core" of the state sector, i.e., of the so-called strategic companies took place in the following crucial areas: electric energy, gas and oil industry, mass media (radio, television), telecommunication and the bank sector. The most important element of this process is not the fact that a privatisational income exceeding 450 billion HUF was produced in 1995, without which, however, the situation of the annual budget would have been critical and financial stabilisation could have hardly been achieved. What is considered more essential is that strategic privatisation also affecting national public utilities dispelled the political uncertainty prevailing in the West vis-a-vis Hungary, therefore, foreign investment was relaunched, the extent of which accreted to 16 billion USD by 1997. Furthermore, the series of privatisations effected in 1995 and 1996 did really swung Hungarian privatisation over the impasse, therefore, by 1997, the

Csillag, I.: Privatizációs szerződések (Privatisation Agreements). Gazdaság és Jog, 2 (1995) No. 7.

${ }^{52}$ For an analysis of the process broken down according to companies, see, Mihályi, P.: A magyar privatizáció krónikája. op. cit. 251-350. See further, Csáki, Gy.-Macher, Á.: A magyarországi privatizáció 10 éve (1988-1997) (A Decade of Privatisation in Hungary: 1988-1997). In: Kurtán-Sándor-Vass (ed.): Magyarország évtizedkönyve. op. cit. 116-130.

${ }^{53}$ For an analysis of the comparison of the law pertaining to privatisation elaborated by the mid-1990s in other former socialist states and in Hungary, see, Sárközy, T.: Rendszerváltozás és a privatizáció joga (The Change of Regime and Law Pertaining to Privatisation). Budapest, 1997. 
expectation that institutional privatisation would be approaching its end was fulfilled. Private property attained a decisive majority in Hungary, thereby, the share of long-term state property in the entrepreneurial sector could be restricted by the millenium to an extent similar to that prevailing in Austria, Italy and France. This has also been brought forth by an increasing scale of privatisation effected by local governments in 1996-1997.

According to my opinion, AP of 1995 (despite its deficiencies also criticised by us) had a paramount role in this internationally recognised result, which was also appreciated in the country report related to the accession of Hungary to the EU. On the basis of the norms set forth under the pertinent statutes of 1992, which were basically focused on the processes of reorganisation, "strategic privatisation" would have been much more circumstantially implementable. According to my view, the criticisms that AP was mere skeleton law, some of its solutions were roughly drafted and allowed for multifarious constructions cannot be substantiated. Undubiously and mainly by reason of the numerous motions for its amendment, there were misformulated rules as well as unravelled provisions under the AP in the absence of practical experience, therefore, they required active contribution on the part of law-appliers (so-called directive norms). At the same time, in the majority of cases, the problems were properly solvable with the generally applied instruments of the interpretation of law assuming that the provisions were benevolently enforced.

Of course, the privatisation of strategic major companies and banks between 1995 and 1997 involved numerous contestable elements. Although, privatisation in principle ensued after several years' preparation, its major part was lowstandard, the overpaid counsellors generally carried out quite slipshod work, the preparation of pertinent regulations (the amendments of acts pertaining to energy and gas supply and to price-formation by authorities, etc.) was also rather ad hoc and a number of legal objections can be made vis-a-vis the concluded agreements. Regrettably, issues were still unvariably over-politicised, the consideration of political aspects was excessively emphatic, which resulted primarily from the composition of the management board of HPSHC. From the outset, the staff of HPSHC in view of its activity was over-dimensioned (it consisted of almost 500 employees), its internal organisational structure was tangled and bureaucratic. The multiple-level system of decision-making was too protracted and involved lots of default possibilities. Fluctuation mainly at the management level of HPSHC was considerable between 1995-2005, the expertise of the apparatus was generally feeble, therefore, it was exposed to external counsellors. Thence, this apparatus was too expensive and inefficient.

Nevertheless, this relatively feeble state apparatus of privatisation and poorly structured organisation did implement the progress of privatisation. 
Succeeding the German privatisation completed by 1995, Hungary was the second socialist state, which, essentially within 10 years, could establish the proprietary structure marking the states of the EU, i.e., which is based on the decisive majority of private property, even if the process included major financial losses, contradictions, sordid social phenomena (albeit, the scale of these, according to my view, was substantially outstripped by those discernible in other former socialist states). First and foremost, we escaped the statecapitalist path. Which, I assume, is a significant achievement in defiance of all well-founded criticisms. The anomalous unity of the roles of the state as public authority and proprietor ceased to exist in Hungary by the end of the 1990s owing to the completion of institutional privatisation, since the change of the proprietary structure of the economic regime had been accomplished, which was regarded as a common irreversible guarantee both of a multi-party parliamentary democratic system and of an economic order based on market competition. In this situation, on the one hand, the legal method of the conclusion of the former intermittent and massive privatisation needed to be elaborated, on the other hand, the new structural, economic and legal order of the utilisation of the persisting state property also needed to be legally regulated.

Within the purview of the statutes of 1991-92, state property had been divided into "government" and "venture" capital, however, this distinction was never supported by refined principal grounds. Theoretically, government property can be essentially divided into two parts: on the one hand, the so-called public property in the strict sense of the phrase (roads, public places, rivers, lakes, etc., which are managed by the state with a view to the benefit of the entire population of the country), on the other hand, the so-called fiscal capital of the state, which substantively constitutes the capital allocated to the budgetary organs of central state administration and local governments. The part of the venture capital of the state not designed to be privatised is essentially not constituted by "free" assets (e.g., real estates), but for the purposes of national economy, it is allocated to the associations, in which the state has a majority ownership, therefore, any regulation concerning these assets essentially implies the determination of the management system of these companies. The basic contradiction of the system established pursuant to Acts 53 and 54 of 1992 (and sustained under AP of 1995) was that these statutes regulated venture capital to be retained in long-term state ownership, but upon the concrete determination of these assets (itemised under the Supplement to AP), they referred exclusively to companies. Therefore, upon the conclusion of institutional privatisation, the capital to be retained in state property permanently, scilicet, for a long term and stably, needed to be recircumscribed. However, that is an issue that basically determines the future economic policy of a 
country, thereby, it may constitute a battleground for social democratic, Christian Democratic or liberal ideologies.

9. Nevertheless, the conclusion of institutional privatisation was deferred by the Horn-Government to the post-election period, whereas, the Orbán-Government in power between 1998-2002 privatised relatively little, what is more, renationalisation was also effected in a low scale. However, the socialist-liberal Governments following 2002 laid a renewed emphasis on the privatisation of the remains of state property that did not belong to government property. By 2005, the law pertaining to the conclusion of institutional privatisation, the cessation of HPSHC and to the organisation of a state holding company (publicly financed institution or joint-venture company) had been drafted, nevertheless, there was a pertinent, fierce, three years' controversy even within the coalition. Therefore, Act 116 of 2007 on the Conclusion of Institutional Privatisation And on a Single State Property Management Organisation took effect as late as on $1^{\text {st }}$ January, 2008. Within the purview of this act, AP of 2005 was annulled and the new organisational and operational order of the management of state property was determined.

N.B., Hungarian experts had reached a consensus already at the end of the 1990s that the scattered management of state property needed to be terminated. Therefore, by the early 2000s, the modern Hungarian fiscus, the Hungarian State Treasury had been established, which has managed the whole range of monetary assets of (the organs of) the Hungarian state deposited on the unified fiscal account. State debts are managed by the Government Debt Management Agency Private Company Limited by Shares. Nonetheless, the real assets of the state were scattered: HPSHC, the Treasury Property Directorate and the Ministries themselves also held state-owned real estates and association shares. Therefore, the establishment of a single organisational and operational structure for the management of the real assets of the state was deemed reasonable. Nonetheless, a dispute emerged in re the organisational form of that trustee:

a) In my view, a State Holding Organisation would have expediently functioned as a publicly financed institution, which, as a so-called Real State Treasury could have later united with the fiscus,

b) According to the other standpoint, the Real State Treasury needed to be established as a joint-stock company for the purpose of the expedient utilisation of the remnants of state property. In this case, the unified management of property would not be governed by the more flexible rules pertaining to government property, which, however, is contestable from a constitutional point of view. 
Eventually, following long disputes and a veto by the Head of State, pursuant to Act 116 of 2007 the second standpoint was adopted and the Hungarian State Holding Company was established as of $1^{\text {st }}$ January, 2008. This close company limited by shares and functioning as a one-entity business association of Government, is not subordinated to a Board of Directors or a Supervisory Board, but its management is accomplished by the State Holding Council consisting of seven members appointed by Government. This company limited by shares manages basically state property, but it is also entitled to its sale, as a matter of course, under safeguarding regulations.

10. I contend that implied the final stage of the history of Hungarian privatisation. We may ponder, whether Hungarian privatisation was a sequence of successes. From institutional-taxonomic and macro-economic points of view and in re the final outcome, I assume the answer is by all means affirmative. Under extremely difficult social-economic and political conditions, the anomalous unity of the roles of the state as public authority and proprietor was de facto terminated and the proprietary structure based on the predominance of private property necessary for the sound functioning of modern market economy emerged. From a strategic point of view, subsequently to the conclusion of privatisation, the future Hungarian state will need to function in a basically different manner from that it did formerly. The state as a proprietor frames a different economic policy from that of the state that establishes a regulatory framework, that can motivate and provide services. The altered task will necessarily and in return affect the organisational and operational mechanisms of the state. Thus, we must be facing a consequential reform in re state organisation and administrative modernisation.

As to its manner of implementation, Hungarian privatisation was naturally not a sequence of successes, either, basically on objective grounds and from the outset, it could not be. In such a profound economic crisis even the chance of optimal privatisation was precluded, assets of such a massive scale could not be so rapidly privatised at an adequate price. Furthermore, as a matter of course, objective reasons were substantially supplemented by subjective flaws: unpreparedness, the absence of experience and of a long-term strategy of privatisation, the standard change of the "conception" concerning privatisation, economic and legal-technical defaults, detriments entailed by over-politicisation, etc. We can also refer to the element that also had a role, namely, that capitalists (i.e., foreign investors) did not know socialist management (scilicet, they ignored socialist precedence), whereas, former socialists did not know capitalist management, scilicet, they could not conform to market economy. Therefore, we have undergone a long-standing process of learning and we 
have learnt severe lessons during privatisation, indeed: in several cases, we could have imposed higher prices, we could have economised on expenditure, we could have elaborated more efficient and skillful privatisational processes and we could have applied more effective privatisational schemes. Finally, what does not entirely belong to the scope of subjective flaws: corruption and abuse could have been more efficiently foreclosed, even if we admit that in the majority of other former socialist states more scandals, corruption and criminality could be discerned than in Hungary, in which we can find scarce solace.

What we can certainly set forth is that our national property has not disappeared, it merely transformed during the process of privatisation. National property seems to have been lost only for those who identify national property with state property and do not recognise that the property of private enterprises and foreign investments in Hungary do become incorporated into our national property. The facts that GDP decreased in the first period of political transformation and that significant unemployment occurred were basically not the consequences of privatisation (on the contrary, in my view, these would have emerged more stringently without privatisation), and in the long-run, privatisation per se actually facilitated the development of our economy. Finally, we could expatiate on the element of social justice. Without doubt, it could not be sufficiently guaranteed by way of privatisation, since individuals in auspicious circumstances and in powerful positions, individuals who realised their social capital (naturally, in many cases these persons belonged to the former state party, to the former state apparatus or company management) could surely acquire much more than others (we do not have precise sociological figures). However, no capitalist system has persisted so far, which would have been based on the property of the majority of the population (which is valid even in case of the most prosperous countries of the world). Why should we suppose that this could have been achieved via a privatisational strategy in Hungary? Even the critics of privatisation acknowledge that "the winners" of privatisation constitute a "mere" 20 p.c. of the population, which as a proportion is not a bad achievement, in my view. Anyway, we are certainly not dealing with a history of privatisation, which has produced some hundreds of millionaire criminals and several millions of deprivated. This is also valid, even if real social considerations should have been more effectively enforced in various areas of economic policy. We must acknowledge that a peculiar form of primitive accumulation of capital ensued (which derived from state property, since we did not possess other property) during an unexpected restructuring from "semi-socialism" into modern capitalism due to world political (and not intrinsic) factors. Just like the English, German, American, etc. primitive accumulation of capital at the dawn of capitalism were ethically quite filthy 
processes taking many decades, the accelerated process of the primitive accumulation of capital taking merely some years could exclusively undergo in an ethically contestable manner. (Its dimension is a moot point.) Nevertheless, the histrorically belated Hungarian system of new-capitalism having evolved by the millenium can eventually prove to be a liveable and habitable society (which is not a groundless expectation), the social dejection brought forth by the shock owing to restructuring may disappear and we may ascend towards "Europe", even if not the entire society, as some presumed, but at least a large segment of the society, mostly the younger generations.

Naturally, the proprietary structure adequate for privatisation and market economy per se does not constitute a guarantee for social-economic success. This framework also allows for faulty economic policies and world economic processes may still destroy national economies. But our new proprietary structure is more viable for facing the challenges of modernisation and globalisation than our economy preceding privatisation was. Namely, in the future private enterprises will rival private enterprises, the possibility of easy acquisition from "soft" state-owned property has been precluded. We allow that several citizens may have acquired great fortunes in the course of privatisation by abusing their positions. Nevertheless, many already demonstrate the inability to hold their grounds in the market, thereby, they will relentlessly fail and the state or politics will not or will hardly be able to "subsidise" them.

We still need time to compile an inventory of and to render a complete, scientific processing of Hungarian privatisation. As far as I am concerned, I would be inclined to qualify it as "optimistically impropitious". In the meantime, passions may also abate, the majority will recognise that not everybody can be a proprietor and that efficient work is more appreciated by private enterprises than by state-owned companies.

As the above elucidate, Hungarian business law was an active contributor to Hungarian privatisation, which took 10 years, and I think it was capable of guaranteeing an operative legal framework for shaping market economy, partially by renewing itself. As a matter of course, there have been mistakes and errors both in law-making and the application of law. Nevertheless, by way of striving towards evolution, maintaining the long-standing elements, simultaneously modernising itself and conforming to the business law of the European Union, law-making could secure appropriate bases for the consolidation of Hungarian private enterprises. 